\section{B A Institute of \\ YK Business Administration \\ तर Karachi \\ Leadership and Ideas for Tomorrow}

Article 8

Volume 8 Issue 1 January-June 2013

$1-1-2013$

\title{
The volatility effect of single stock futures trading on Pakistani Stock Market
}

Adil Awan

SZABIST, Islamabad, Pakistan

Amir Rafique

SZABIST, Islamabad, Pakistan

Follow this and additional works at: https://ir.iba.edu.pk/businessreview

Part of the Business Commons

(c) (i)

This work is licensed under a Creative Commons Attribution 4.0 International License.

\section{Recommended Citation}

Awan, A., \& Rafique, A. (2013). The volatility effect of single stock futures trading on Pakistani Stock Market. Business Review, 8(1), 94-122. Retrieved from https://doi.org/10.54784/1990-6587.1219

This article is brought to you by iRepository for open access under the Creative Commons Attribution 4.0 License and is available at https://ir.iba.edu.pk/businessreview/vol8/iss1/8. For more information, please contact irepository@iba.edu.pk. 


\title{
ARTICLE
}

\section{The Volatility effect of Single Stock Futures Trading on Pakistani Stock Market}

\author{
Adil Awan \\ Szabist, Islamabad, Pakistan \\ Amir Rafique \\ Szabist, Islamabad, Pakistan.
}

\begin{abstract}
The impact of single stock futures on the spot market volatility is still a issue debated in finance literature. The aim of this study is to analyze the effect of introduction of single stock futures on the volatility of Karachi Stock Exchange. This study mainly addresses the changes in level of volatility and structure after the introduction of single stock futures. Twenty four companies listed on KSE were evaluated in terms of possible volatility effect due to stock futures trading. This study applied F-test for differences in variances as a traditional measure for volatility and $\mathrm{GARCH}(1,1)$ as a econometric technique for detecting time-varying volatility. The results showed that there was no effect on volatility level and changes were experienced with structure of volatility after stock futures trading.
\end{abstract}

Key words: Single stock futures, Derivatives, volatility.

\section{Introduction}

Stock market volatility is the most vital area of research from the last three decades. Volatility is a risk measure and widely used in finance studies. Major interest of researchers on volatility studies is due to risk assessment of any security or market. There has been extensive debate on derivatives trading (index futures and index options) and its impact on the underlying spot market. The general perception about derivatives is that they have increased stock prices but there is no common agreement among researchers due to mixed empirical evidence. Impact of introduction of derivatives security (futures and options) on the underlying spot market is a less researched area and there is a little consensus among researchers and practitioners on this issue. Therefore, due to differences in theoretical framework and varied empirical findings, there is no unanimous conclusion that futures trading has stabilized or destabilized the spot market.

Future contracts are introduced in the stock market for managing and minimizing risk in the underlying spot market. Single stock futures are contracts which are traded on stock exchanges. These contracts are future commitments to buy or sell shares at a fixed rate of any specific listed company. Single stock futures are part of derivatives and their price is dependent on 
ordinary shares. As these contracts expires, the holder of the contact buys at predetermined price from the seller. This type of physical delivery contracts is called deliverable futures contracts. Determination of gain or loss is done on expiration of contracts. The difference between the spot and futures price is the actual gain or loss of the contract. Nowadays, cash settles futures contracts are available in which daily settlement of contracts is done by the stock exchange.

The link between the spot and futures market can be explained by cost of carry concept. Strong (2005) defined this concept as, " net cost incurred for carrying an asset forward in time". There are two types of net costs, one is carrying returns (dividends) and other is carrying charges (interest).The fair value of future contract is determined by the spot price of underlying asset and cost of carry. This concept has established the link between two markets. Futures contract price is function and dependent on the underlying spot price. It is plausible that a reciprocal relation exists between two markets.

Introduction of single stock futures has given the opportunity to researchers for reinvestigating futures trading comprehensively. Stock futures offer direct assessment of probable impact on underlying shares. Market-wide impacts of futures trading can be assessed by index futures whereas companywide impacts can be assessed by single stock futures.

\section{Contextual Analysis}

Pakistani stock market comprises of three stock exchanges. Karachi Stock Exchange (KSE) is the largest and oldest exchange. KSE is the most liquid and active exchange in Pakistan. KSE was established in 1947. and provides products like ready market, index futures and stock futures. Trading in stock futures started in July 1, 2001 and Index futures started in April 1, 2008. Pakistani stock market has faced many problems in its development like other developing countries. From the last few years, KSE has witnessed extra-ordinary volatility, and it is considered one of the most volatile markets in the world. Stock futures trading in Pakistan started with ten companies in 2001, and they have increased to forty six companies in 2008 (Khan, Shah and Abbas, 2011).

\section{Significance of the study}

Traditionally, futures markets are considered more volatile than the spot market. The close linkage between the two markets creates the risk transfer possibility from one market to another. Previous researches reported different findings about futures trading. Some documented increase in volatility, some stated decrease in volatility and other supported mixed results. As there is no consensus among researchers on this issue, so a study is needed on this important issue in finance. The research on single stock futures in Pakistan has got less attention of researchers. This study fills this gap by adding to existing body of knowledge. Past studies on volatility effect of SSF's contracts on the underlying spot market were investigated in developed countries, but few studies conducted in the developing country like Pakistan. This study will be good addition from developing country perspective to this new area of research. This study will analyze companywide impacts rather market-wide impacts, so direct evaluation of possible effect can be reported. This study will be helpful to various stake-holders such as practitioners, academics, investors and regulators. 


\section{Problem statement}

Futures markets are considered more volatile than the spot market, so they can be a source of volatility for spot market. As futures trading can increase volatility in the underlying spot market, a study is needed to investigate whether stock futures increase or decrease spot market volatility. The impact of stock futures trading on the underlying spot market has not been investigated comprehensively by researchers. Research on this area in Pakistan is very little and by no means exhaustive.

\section{Aim of this research}

The aim of this research is to determine the impact of introducing single stock futures on the volatility of the security.

\section{Research objectives}

This study intends to achieve following objectives:

1. To study the changes in the volatility level after the introduction of single stock futures trading in Pakistan.

2. To investigate changes in volatility structure after single stock futures trading in Pakistan.

\section{Research Question}

To what extent single stock futures impact underlying spot market volatility?

\section{Delimitations of study}

- This study investigated only Pakistani context.

- Sample firms included on the basis of data availability.

- $\quad$ This study will be delimited from July 1, 2001 to December, 2010.

\section{Literature Review}

Over the years, two views about derivative markets have been developed to clarify why derivative trading may affect the spot market volatility. This discussion focuses on the arbitrage activities which links the derivatives market with spot market. These contrasting views depend on the assumptions regarding arbitrageurs. A key assumption made about derivative trading is whether they bring informed or uniformed traders to stock market. One view is pro-derivative, stating that derivatives trading bring informed traders to market and these informed traders will bring efficiency and lowers volatility in underlying market. Second view is anti-derivative, stating that derivative trading has brought speculators which are involved in massive and irrational speculative activities (Robbani and Bhuyan, 2005).

Derivative markets have several advantages as compared to trading in spot market. Main benefits are low transaction cost, high leverage and greatest liquidity. Futures trading allow 
investors to take market-wide exposure with low transaction exposure. Investors take large positions in futures trading as compared to spot market. The advantage of high degree of leverage provided by futures trading can attract uniformed traders or speculators to both markets. These uninformed and irrational traders for their short-term profits can increase the volatility of underlying market. Futures markets are affected by this speculation due to low transaction costs. These uninformed traders or irrational speculators trading in futures market can destabilize underlying spot market. This view is known as anti-derivative or destabilizing effect of futures market.

Robbani and Bhuyan (2005) differentiate between informed and uninformed trader. Informed traders carry out arbitraging activities and uniformed trader involves in speculative activities. Increase in informed traders attracted to the markets will increase trading volumes and lead to lower volatility in underlying spot market. This is Pro-derivative view or stabilizing effect of futures trading. This view remains intact if no trading volumes are transferred to futures markets. If the trading volumes diverts, it can lead to low trading volumes and increased volatility in spot market. Faff and Hillier (2003) stated that if there are new financial innovations like derivative products, the informed traders can be attracted to futures market due to low transaction cost and high leverage. Trading volumes would be diverted to futures market and lead to destabilization of spot market.

Peat and McCorry (1997) were pioneer researchers on single stock futures. They have opposite view to this discussion of future trading leading to market stabilization or destabilization. After the advent of stock futures if market moves towards stabilization or completion; there would be increase in share prices resulting in low required rate of returns, increase in trading volumes and decrease in spot market volatility. If market is destabilized after the advent of stock futures; there would be decrease in share prices resulting in higher required returns, decrease in trading volumes due to migration towards futures markets and leading to increase in spot market volatility.

\section{Decreased volatility due to futures trading}

Elfakhani and Chaudhury (1995) studied the effect of introduction of options on Canadian spot market. They claim that there was a reduction of risk in both total risk and systematic risk in early 1970s due to options trading. They observe that in late 1980s, near the market crash of 1987 the systematic risk of underlying individual equity shares was increased due to listing of options contracts. It was concluded that options listing has been stabilizing effect on the underlying spot market except for the market crash of 1987. Chatrath, Ramchander, and Song (1995) test the hypothesis that " does option trading increases the spot market volatility or not " in US market. Their result exhibited that options trading has reduced volatility in spot market but increased volatility of spot market has increased volatility in options trading. Overall, the options trading have reduced risk in the underlying market. A paper by Mckenzie, Brailsford and Faff (2000) find significant and prominent reduction in unconditional volatility and decline in systematic risk. There was slower incorporation of information in prices, shorter impact of old news and lower effect of persistence of shocks. Bologna and Cavallo (2002) attempted to study whether Stock Index Futures Contract (SIFC) reduced volatility of stock market or not? The study observed reduction in volatility and increased efficiency of spot market due to SIFC. This evidence was 
supported by decrease in unconditional volatility. Results revealed that new information was being incorporated more rapidly in prices (more clustering), but this impact was not long-lasting (less persistence). The persistence of shocks(ARCH + GARCH term) was also declined from pre to post period, which strengthens stabilizing hypothesis of futures trading. Ang and Cheng (2005) attempt to investigate whether financial innovation's introduction can improve market efficiency or not. They tested market efficiency by applying a "specific announcement of news". If there were few excess unexplained post listing price changes of SSF firms, then market is efficient. Their results supported that market become efficient after SSF trading. They attributed market efficiency to increase trading in futures market, high leverage and low transaction cost, which benefited arbitrageurs rather than speculators. Mazouz and Bowe (2006) investigated volatility effect of SSF's contract on London's stock exchange. There was the reduction in unconditional volatility and systematic risk. Due to futures trading, the current news is incorporated in prices more rapidly, shorter impact of old news and lower shocks effect. Drimbetas, Sariannidis and Porfiris (2007) reported effect of the index futures contract on the underlying equity market in Greece. They used FTSE/ASE twenty as the underlying index. The period of study was 19972005. Exponential GARCH model was adopted for volatility analysis. There was the reduction in volatility post futures trading and no change was seen in the structure of volatility. However, unconditional volatility decreased after introduction of futures. De Beer (2008) investigated single stock futures effect on South African stock market. The volatility of underlying equity market was reduced and there was no change in systematic risk.There was faster incorporation of new news, shorter impact of old news and lower shocks effect. Khan (2006) studied futures trading impact on spot volatility in Pakistan. Results support that for incorporating new information, spot market leads the futures market. Futures market is not responsible for the volatility in the spot market. The findings concluded that volatility in the futures market is due to the outgrowth of spot market. Khan and Hijazi (2009) examined single stock futures trading and share price volatility in Pakistan. Results showed that there was a reduction in stock price volatility after introduction of futures trading. However, there was positive relation between spot volumes and spot volatility. This study supports stabilizing effect of futures trading.

\section{Increased volatility due to futures trading}

Peat and McCorry (1997) carried out one of the first empirical study on the role of Single Stock Futures (SSF) on Australian spot market. They based their study on existing literature of introduction of options and stock index futures contract on underlying equity market. They tested complete markets theory, diminishing short sales theory and improved information environment hypothesis. Their results contradicted earlier findings of introduction of derivatives trading. Previous studies supported the argument that market becomes complete after introduction of derivative trading. Introduction of options has reported increase in price and volumes but volatility has decreased. However, their study claims that there is no effect on price but increase in volumes and volatility. According to the study by Smit and Nienaber (1997) on "futures trading activity and stock price volatility in South Africa, "Futures trading activity refers to volume and open interest on the stocks." They applied regression for analysis. Results depicts that more activity in futures leads to more volatility in the underlying spot market. Swart (1998) conducted a research on impact of index futures on the volatility and liquidity on underlying Johannesburg Stock Exchange (JSE) in South Africa. Increase in volume and volatility in the underlying market was due to increase in index futures trading. Butterworth (2000) supported the argument that futures trading 
have changed the structure and level of volatility of spot market. There was less volatility clustering but more volatility persistence in returns after introduction of futures trading. There was a considerable increase in constant term but huge rise in unconditional variance in variance equation. They concluded futures have beneficial effect on spot market. Faff and Hillier (2003) analyzed "complete markets, improved information environment and diminishing short sales theory on options introduction" in United Kingdom. They constructed a sample of eighty six companies involved in options trading. The sample period of study was 1978-1999. The price effect was tested by event study methodology. The abnormal returns were calculated through market model. Positive abnormal returns were seen after introduction of options trading but there was not visible pattern over the period of time. Volume effect was estimated through dummy variable regression. This analysis suggests that there was rise in level of trading volumes following introduction of options trading. Volatility effect was measured through dummy variable regression. Results show that there is rise in the level of volatility post options trading. Bae, Kwon and Park (2004) studied the effect of futures trading on stock market efficiency and volatility in Korean context. They used a sample consisting of KOSPI 200 and control sample. The period of study was 1990-1998. Dummy variable regression was used for volatility analysis. Results showed that destabilizing effect and increase in volatility of underlying spot market. Aitken and Segara (2005) studied initiation impact of Australian warrants on underlying individual equity shares. Returns of shares showed a decline after introduction of warrants. Both volume and volatility of spot market rose after initiation of warrants. Ahmad, Shah and Shah (2010) conducted a research on impact of futures trading on spot price volatility in Pakistan. The returns showed both clustering and persistence. Kse-100 was found to predict both spot and futures market. However, Spot and futures market do not Granger cause each other but also the market index. All markets were found highly volatile in nature and that was the cause of increased volatility for one another. Consequently, this study supported destabilizing hypothesis of futures trading in contrast to previous studies in Pakistan.

\section{Mixed evidence of futures trading}

Oehley (1995) investigated the impact of introduction Stock index futures contract (SIFC) on the underlying market index in South Africa. Results did not provide any evidence that introduction of futures trading increased volatility. The general increase in share market volatility was due to 1987 market crash. However, SIFC was not attributed for increasing volatility of index. Darrat and Rahman (1995) substantiated evidence from U.S market about "futures trading and its impact on share price volatility. They reported that futures trading had not increased volatility of underlying equity market. There was evidence of spike volatility in the sample period, but it was not attributed to futures trading. Hence, volatility of Over the Counter (OTC) index and term structure was responsible for volatility in stock prices. Parsons (1996) studied futures trading and its impact on the cash (spot) market in the context of South Africa. The results depicted that there was no increase in volatility of underlying indexes, which supported stabilizing effect of futures trading. Vanden Baviere and De Villiers (1997) studied " stock price volatility after the introduction of Index futures". The findings did not provide any evidence for increased to the level of volatility of firms that were constituent of the market index. Lee and Tong (1998) analyzed emergence of Individual Stock Futures (ISF) contracts in the Australian equity market. They reported that increase in the level of volumes and no effect on volatility due to introduction of stock futures. Their studied suggested increase in volumes due to more participation of firms 
because future trading expanded investment opportunities and resulted into risk reduction. Dennis and Sim (1999) computed volatility of introduction of ISF contracts on Sydney future exchange. Their findings exhibited that trading in the spot market has the huge effect on the volatility of spot market rather than trading in the futures market. Consequently, they substantiated that there is minor effect of beginning of ISF contracts on the volatility of cash market. A paper by Kruger (2000) on index futures and stock price volatility in South Africa suggested that futures trading did not increase volatility in equity indices. As the date of expiration of a futures contract is near, there is an increase in futures trading. Hung, Lee and So (2003) conducted a research on impact of SSF contracts listed in foreign stock exchanges on the underlying domestic equity market. They find evidence that SSF contracts listed in foreign countries are increasing volatility on an underlying domestic equity market. Moreover, the daily shock in foreign listed SSF firm is increasing conditional volatility in their respective home underlying equity market. Besides, reduction in conditional volatility was seen as a result of high variable and predictable activity across the days. There were no differences in unconditional volatility from pre to post futures period. There was slower incorporation of information in prices, shorter impact of old news and lower shocks effect. Mazouz (2004) in his study on the effect of equity options introduction on NYSE (United States). The study adopted GARCH model. Findings show no effect of equity options on both unconditional and conditional volatility. Kumar and Mukhopadhyay (2004) examined futures trading and its impact on the underlying Indian equity market. There were no-effect index futures trading on both average and additional level of volatility. The new information was being incorporated in prices but old information, and shock's effect was less persistent. A study by Robbani and Bhuyan (2005) on the volume and volatility effect of futures and options trading on stock market index of United States investigated thirty companies that are part of DJIA index. The sample period was 1989 to 1994.For analysis they applied t-test, f-test, Wilcoxon signed rank test, Parkinson's estimator and GARCH for time varying volatility. Returns of all underlying firms showed no effect as result of derivative trading. However, trading volume of twenty three companies tend to increase after derivative trading. There was increase in conditional volatility post futures and options trading but there was no increase in unconditional volatility. There was faster incorporation of new news and longer impact of old news which results in higher shocks effect. Chau, Holmes and Paudyal (2005) studied cross border and domestic listing of SSF contracts on underlying market volatility and feedback trading in UK. The findings reported improvement in market efficiency; reduce volatility in the underlying and little decrease in level of feedback trading. They were obvious differences among industries in terms of market dynamics. Positive impact on the underlying market from pre to post period is not related to futures trading. A constant component was used to model serial auto-correlation presented in the possible market in-efficiency. The improvement in efficiency was due to reduction in that component. Clarke, Gannon and Vinning (2007) analyzed introduction warrants in Australian stock market. It was seen that there was no difference in volatility after warrant's introduction. Recently, a paper by Khan, Shah and Abbas ( 2011) explored single stock futures trading and its impact on stock prices. Both traditional and econometric analysis depicts mixed results. GJR-GARCH analysis showed limited and fractional decrease in volatility for both SSF firms and control sample. Thus, this partial reduction can be attributed to other markets wide factors but not to futures trading.

Consequently, majority of past studies suggest that derivative trading no effect on volatility of underlying spot market. Majority of past studies on single stock futures are conducted in United States, United Kingdom, Australia and South- Africa. Majority studies find that there is mixed evidence on volatility. Previous researches on derivatives trading like warrants, options and stock 
index futures contract provided varied and indecisive results. In Pakistan, most of the studies focused on futures trading and some of them investigated single stock futures. Generally, there is no conclusive study on futures trading.

\section{Theoretical framework}

Complete Markets hypothesis, the Diminishing Short-Sales Restrictions hypothesis and the Improved Information Environment hypothesis by Ross (1976), Miller (1977), DeTemple \& Seldon (1991) and Figlewski \& Webb (1993). These all theories provided a conceptual framework about impact of option introduction on the underlying spot market.

Theory of complete markets by Ross (1976) and Arditti \& John (1980) states that options introduction has increased the opportunities for investors in terms of risk/return patterns. Options have provided more favorable and attractive positions for investors as they were not available prior to their introduction. Expansion and improvement in opportunity set will increase the demand of shares and as a result there is an increase in equilibrium prices.

The diminishing short sales theory states that the options introductions can make markets complete by allowing the short positions. These synthetic short positions allow investors who have the negative view on shares, so they can trade on their information which they were not allowed previously without options. Informational efficiency is restricted by short sales constraints and negative information cannot be incorporated in prices (Miller, 1977). In this situation only optimistic investors will buy shares, there would be an imbalance in supply-demand and as a result there would be increased in equilibrium prices. As there is availability of short positions in the derivative market which resulted in supply-demand imbalances. These imbalances are corrected by arbitrage and there is a decrease in prices.

Improved information environment hypothesis has many dimensions and there is no sole statement by theorists on it. It favors the removal of the short sales-hypothesis, by which informed traders having negative information can trade and get profit from better information than others. Another dimension of this theory states that introduction of derivative trading will bring the increase in analyst and coverage of media and this change the investment mix (insider traders/speculators/uninformed traders) in underlying stock.

The vast amount of past studies on the area of impacts of derivative trading on the underlying equity market is based on futures introduction, with limited studies available on introduction of single stock futures trading. Besides, most of the past studies on derivative trading and their impact on the underlying spot market are based on options introduction. Both single stock futures and options are from same category of derivatives, so they share similar characteristics with different patterns of returns and leverage, but we assume theories to hold for them. 


\section{Research Methodology}

\section{Data and sample}

Firstly, the sample of the study was filtered by particular criteria. The selection criterion of SSFs is following: (I) Any SSFs delisted during the sample period was excluded from analysis. (ii) A stock must have 500 days of spot price data for both pre and post event. Secondly, sample time period of analysis was determined from past studies. In previous studies, time period selected was varying from three months to three years. So, to avoid any bias in study researcher has selected two year pre and post data for SSFs. Trading in individual stock futures on the Karachi Stock Exchange commenced in July 2001. The sample period of this study begins July 1, 2000 and ends December, 2010.Till June (2008) forty six single stock firms were identified by Khan, Shah and Abbas (2011). Twenty four firms. Daily closing share prices were obtained from the online database of Karachi Stock Exchange for a period of one year prior, to one year after the listing of each stock, yielding more than 500 daily observations per stock for each of the sub-periods.

\section{Hypothesis}

H0: Introduction of Single stock futures has no impact on the underlying volatility.

$\mathrm{H}_{\mathrm{A}}$ : Introduction of Single stock futures causes either a positive or negative impact on the underlying volatility.

\section{Data analysis techniques}

\section{Calculation of Returns}

This study uses the following formula for calculating returns for each stock:<smiles>[R]CCCCCCCCCCCCC(C)[R7]([Y7])I</smiles>

$\mathrm{R}_{\mathrm{it}}=$ Return of security $i$ in period $\mathrm{t}$

$\mathrm{P}_{\mathrm{t}}=$ Closing price of security $i$ on day $\mathrm{t}$

$\mathrm{P}_{\mathrm{t}-1}=$ Closing price of security $i$ on the day $\mathrm{t}-1$

\section{Volatility effect}

Volatility is statistical measure used to capture the tendency of any security or market to sharply rise or fall over period of time. It is widely used in finance studies. It is used as a proxy for assessing risk in any security or market. Volatility can be measured by standard deviation, variance and beta.

According to the framework provided by major theories, the probable effect of stock futures trading on the underlying spot market is provided as follows: 
Expected change in underlying spot market

\begin{tabular}{llll}
\hline & Complete market's theory & $\begin{array}{l}\text { Diminishing short } \\
\text { sales restriction } \\
\text { theory }\end{array}$ & $\begin{array}{l}\text { Improved Information } \\
\text { Environment hypothesis }\end{array}$ \\
\hline Volatility & Lower & Lower & Lower \\
\hline
\end{tabular}

Source: Clarke, Gannon and Vinning (2007)

Firstly, F-test for differences in variance was used for preliminary investigation of volatility. Secondly, Generalized Autoregressive Conditional Heteroskedasticity (GARCH) was employed as major methodology for capturing changes in conditional volatility.

\section{F-test of difference in Variance}

Variance is a measure of volatility. Larger the variance among the returns represents higher volatility and more riskiness of the security or market. It is calculated as a mean sum of squares of difference between values and means of security sample. F-test is a traditional measure to examine changes in volatility (unconditional variances).It It is applied to the ratio of pre-SSFs versus postSSFs.

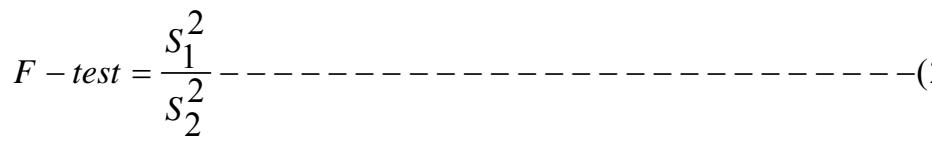

$\mathrm{S}_{1=}^{2}$ Pre-event variance

$\mathrm{S}_{2}^{2}=$ Post-event variance

Auto-regressive conditional heteroskedasticity

The assumptions of OLS regression are expected value of residuals should be zero, constant variance of residual terms and no auto-correlation in the data series. The constant variance assumption of error terms is also known as homoskedasticity. The basis of ARCH or GARCH modeling is the violation of homoskedasticity assumption. The $\mathrm{ARCH}$ effect is present in time series that has not been constant variance (heteroskedastic).

Autoregressive conditional heteroskedasticity $(\mathrm{ARCH})$ is a condition when variance of error terms in one period is dependent on variance of error terms in the previous period. In this situation, hypothesis test of regression coefficients and their standard errors will be invalid. ARCH or GARCH modeling considers heteroskedasticity not a problem which is to be corrected but rather variance included in modeling(Engle, 2001).ARCH/GARCH models have corrected OLS deficiencies with meeting required assumptions. The features of GARCH models, they have constant unconditional variance, conditionally heteroskedastic and mean reverting.

Engle (1982) introduced ARCH modeling. These models are particularly designed for modeling and forecasting conditional volatility. Bollershev (1986) introduced GARCH (Generalized $\mathrm{ARCH}$ ) modeling. In ARCH model, dependent variable variance is included in the model as a function of independent variables and its past values. In GARCH (p,q) model, conditional volatility (variance) is a function of lagged terms of conditional variance and past squared error terms. 
Engle (2001) stated standard GARCH (p, q) has two standard terms. The first term (p) shows the number of ARCH terms (autoregressive lags included in the model),) and second term (q) shows GARCH terms(number of moving average lags).GARCH(1,1) refers to existence of $\mathrm{ARCH}$ and GARCH term of first order. Volatility clustering is captured by GARCH models. According to Engle (1993), volatility clustering is referred as high volatility followed by more tranquil periods of low volatility.

GARCH $(1,1)$ Model

Basic GARCH $(1,1)$ specification:

Mean equation

$y_{t}=\alpha+\beta y_{t-1}+\varepsilon_{t} \ldots \ldots \varepsilon_{t}\left(o, h_{t}\right)$

$\mathrm{y}_{\mathrm{t}}=$ return on security

$\alpha=$ constant

$\beta \mathrm{y}_{\mathrm{t}-1}=$ Autoregressive coefficient and explanatory (lagged) variable

$\varepsilon_{\mathrm{t}}=$ residual term

\section{Variance equation}

$$
h_{t}=\omega+\alpha \varepsilon_{t-1}^{2}+\beta h_{t-1 \ldots \ldots \ldots . . .} \omega>0, \alpha>0, \beta \geq 0
$$

Unconditional constant variance of error term

$$
\operatorname{var}\left(\varepsilon_{t}\right)=\frac{\omega}{1-\alpha-\beta}
$$

$\mathrm{h}_{\mathrm{t}}=$ Conditional variance in period $\mathrm{t}$

$\omega=$ Constant (long-term average)

$\alpha \varepsilon_{\mathrm{t}-1}^{2}=$ News coefficient and ARCH(1) term

$\beta \mathrm{h}_{\mathrm{t}-1}=$ Persistence coefficient (old news and GARCH(1) term

Source: Brooks (2008)

The variance equation consists of three terms:

- constant: $\omega$

- $\quad$ information regarding previous period volatility (ARCH term)

- forecasted variance of last period (GARCH term)

Source: Eviews (2007)

Current asset price is explained by auto-regressive component in the mean equation. In variance equation, error terms are modeled to be time-varying rather than constant. The parameters of $\operatorname{GARCH}(1,1)$ show that current volatility is a function of past squared error terms and an auto-regressive component of the conditional variance. Engle (2001) states that for a mean reverting variance process the parameters estimated from GARCH model should be positive and their value should not be greater than one. 
De Beer (2008) states GARCH equation has two main effects. Firstly, impact of recent information to market (ARCH effect) and the effect of old information to market (GARCH effect). It is important statistically to know that whether recent news is important than old news to the market. The detection of current and lasting impact is measured by the changes in the size of $\mathrm{ARCH}$ and GARCH effect. The volatility persistence can be measured by adding two effects.

De Beer (2008) states that a sample will follow volatility clustering and persistence if both $\mathrm{ARCH}$ and GARCH terms are significant. This volatility clustering and persistency process shows that if there is a shock in stock prices, it will persist for many successive periods. A shock or jolt in share prices will last for a short period if the ARCH and GARCH terms are insignificant.

In the same way, if there is an increase (decrease) in ARCH (1) term from the pre-event sub sample to post-event sample, then there is faster (slower) dissemination of information (news) on the stock prices. If there is an increase (decrease) in GARCH (1) term from the pre-event sub sample to post-event sample, then there is the long-lasting effect of old news on share prices. The auto-regressive root which is the sum of ARCH plus GARCH term values, it shows the tendency of specific stock to show the impact and after effect of jolt or shock on the price. AR root show the persistence of shocks.

ARCH (1) and GARCH (1) effects are tested separately for pre-event sub sample and a post-event sub sample. Change in unconditional variance can be measured by introducing a dummy variable in conditional variance equation. Dummy variable for the pre-event it is zero and post-event is one. Futures trading will increase (decrease) volatility if there is a significant positive (negative) dummy variable coefficient.

Variance equation, including Dummy variable

$$
\begin{aligned}
& h_{t}=\omega+\alpha \varepsilon_{t-1}^{2}+\beta h_{t-1}+\delta D_{F} \\
& \operatorname{var}\left(\varepsilon_{t}\right)=\frac{\omega+\delta}{1-\alpha-\beta} \\
& \delta=\text { coefficient } \\
& D_{\mathrm{f}}=\text { dummy variable }
\end{aligned}
$$

Results and Discussion

1.1 Descriptive statistics of Pre and Post event period of individual shares

\begin{tabular}{lllccccc}
\hline & & Mean & Median & $\begin{array}{c}\text { Std. } \\
\text { Dev. }\end{array}$ & Skewness & Kurtosis & $\begin{array}{l}\text { J.B.(P- } \\
\text { value) }\end{array}$ \\
\hline ENGRO & PRE & -0.001 & -0.002 & 0.029976 & -0.128 & 11.56474 & 0.000 \\
& POST & 0.000997 & 0.000614 & 0.024221 & -0.004 & 6.013720 & 0.000 \\
FABL & PRE & 0.002103 & 0.001458 & 0.027585 & -0.471 & 7.949325 & 0.000 \\
& POST & 0.001521 & 0.001356 & 0.029189 & -1.262 & 10.15042 & 0.000 \\
FFBL & PRE & 0.003289 & 0.000000 & 0.041945 & 0.345826 & 7.808736 & 0.000 \\
& POST & 0.001407 & 0.000000 & 0.025513 & 0.339097 & 4.134581 & 0.000
\end{tabular}




\begin{tabular}{|c|c|c|c|c|c|c|c|}
\hline \multicolumn{6}{|c|}{ Business Review - Volume 8 Number 1} & \multicolumn{2}{|c|}{ January - June 2013} \\
\hline \multirow[t]{2}{*}{ FFC } & PRE & 0.000 & 0.000000 & 0.027886 & -1.666 & 43.28937 & 0.000 \\
\hline & POST & 0.002134 & 0.001447 & 0.020634 & -0.270 & 5.836772 & 0.000 \\
\hline \multirow[t]{2}{*}{ HUB } & PRE & 0.000635 & 0.000000 & 0.030108 & 0.139531 & 6.856852 & 0.000 \\
\hline & POST & 0.001552 & 0.001992 & 0.027161 & -0.744 & 9.792955 & 0.000 \\
\hline \multirow[t]{2}{*}{ KESC } & PRE & 0.001173 & 0.000000 & 0.034128 & 1.215301 & 8.635981 & 0.000 \\
\hline & POST & -0.002 & 0.000000 & 0.029418 & 0.819180 & 8.233262 & 0.000 \\
\hline \multirow[t]{2}{*}{ LUCKY } & PRE & 0.002804 & 0.000000 & 0.028679 & 0.347713 & 3.876507 & 0.000002 \\
\hline & POST & 0.002092 & 0.002304 & 0.027287 & -0.051 & 3.494917 & 0.069852 \\
\hline \multirow[t]{2}{*}{ MPLF } & PRE & 0.003163 & 0.000000 & 0.032238 & 0.377267 & 3.523883 & 0.000152 \\
\hline & POST & -0.001 & 0.000000 & 0.027643 & -0.069 & 3.532435 & 0.042739 \\
\hline \multirow[t]{2}{*}{ NML } & PRE & 0.001104 & 0.000000 & 0.037895 & -0.988 & 12.99042 & 0.000 \\
\hline & POST & 0.001639 & 0.000000 & 0.033319 & 0.335330 & 4.906277 & 0.000 \\
\hline \multirow[t]{2}{*}{ PIA } & PRE & -0.002 & 0.000000 & 0.030568 & -0.061 & 4.965522 & 0.000 \\
\hline & POST & 0.002502 & 0.000000 & 0.042873 & 0.974915 & 7.807721 & 0.000 \\
\hline \multirow[t]{2}{*}{ PIOC } & PRE & 0.003450 & 0.000000 & 0.032683 & 0.104470 & 5.874602 & 0.000 \\
\hline & POST & -0.002 & -0.002 & 0.029352 & -0.086 & 3.034602 & 0.723754 \\
\hline \multirow[t]{2}{*}{ PSO } & PRE & 0.000637 & 0.000275 & 0.027285 & -0.123 & 10.57158 & 0.000 \\
\hline & POST & 0.001362 & 0.000623 & 0.026797 & -0.095 & 5.823495 & 0.000 \\
\hline \multirow[t]{2}{*}{ PTCL } & PRE & 0.000 & 0.000000 & 0.022892 & 0.125436 & 8.996783 & 0.000 \\
\hline & POST & 0.001181 & 0.000000 & 0.024341 & -0.142 & 7.297403 & 0.000 \\
\hline \multirow[t]{2}{*}{ SNGP } & PRE & 0.000303 & 0.000000 & 0.035134 & 0.280865 & 10.54835 & 0.000 \\
\hline & POST & 0.002487 & 0.000000 & 0.029891 & -0.185 & 7.444145 & 0.000 \\
\hline \multirow[t]{2}{*}{ SSGP } & PRE & 0.001921 & 0.000000 & 0.025665 & 0.237348 & 4.508559 & 0.000 \\
\hline & POST & 0.000 & -0.002 & 0.025778 & 0.055356 & 3.496147 & 0.067755 \\
\hline \multirow[t]{2}{*}{ TELE } & PRE & 0.000688 & 0.000000 & 0.030216 & 0.259989 & 4.657943 & 0.000 \\
\hline & POST & -0.001 & -0.004 & 0.035922 & -0.886 & 14.22332 & 0.000 \\
\hline \multirow[t]{2}{*}{$\mathrm{ABL}$} & PRE & -0.002 & -0.001 & 0.030599 & -0.280 & 4.571490 & 0.000 \\
\hline & POST & 0.001883 & 0.000000 & 0.026991 & -0.066 & 4.254456 & 0.000 \\
\hline \multirow[t]{2}{*}{ NETSOL } & PRE & -0.001 & -0.002 & 0.052528 & -13.231 & 250.2266 & 0.000 \\
\hline & POST & -0.003 & -0.005 & 0.047136 & 0.745493 & 9.684422 & 0.000 \\
\hline \multirow[t]{2}{*}{ FCCL } & PRE & -0.001 & 0.000000 & 0.026065 & -0.124 & 3.794509 & 0.000738 \\
\hline & POST & -0.002 & -0.003 & 0.041262 & 0.012739 & 8.917209 & 0.000 \\
\hline \multirow[t]{2}{*}{ CSAP } & PRE & 0.000109 & -0.001 & 0.028581 & -0.817 & 7.022855 & 0.000 \\
\hline & POST & -0.002 & -0.003 & 0.034682 & -2.018 & 23.96737 & 0.000 \\
\hline \multirow[t]{2}{*}{ ATRL } & PRE & 0.000624 & 0.000000 & 0.030562 & -0.820 & 7.005381 & 0.000 \\
\hline & POST & -0.002 & 0.000 & 0.037650 & -1.764 & 14.90924 & 0.000 \\
\hline \multirow[t]{2}{*}{ PRL } & PRE & -0.003 & -0.002 & 0.026916 & -0.224 & 4.243145 & 0.000 \\
\hline & POST & 0.001151 & -0.001 & 0.028255 & 0.032965 & 2.669006 & 0.305289 \\
\hline \multirow[t]{2}{*}{ PICT } & PRE & -0.002 & -0.001 & 0.030599 & -0.280 & 4.571490 & 0.000 \\
\hline & POST & 0.001883 & 0.000000 & 0.026991 & -0.066 & 4.254456 & 0.000 \\
\hline \multirow[t]{2}{*}{ WTL } & PRE & 0.000779 & -0.003 & 0.027665 & 0.308685 & 4.098218 & 0.000 \\
\hline & POST & -0.002 & 0.000000 & 0.053642 & 0.112598 & 7.240552 & 0.000 \\
\hline
\end{tabular}




\section{Descriptive Analysis}

The descriptive analysis tells us the behavior of data with respect to normality. In majority of cases, Jarque-Berra statistics show that returns are not normal. In post-event period, PIOC and PRL exhibited normal distribution. All the shares show excess kurtosis. Positive excess kurtosis shows leptokurtic behavior of returns. Negative skewness is prevailed in the majority of the shares. Financial data usually exhibit non normal behavior which is also evident in this return series. ADF test is applied for checking unit root in series. If there is unit root, series will be nonstationary, which can lead to spurious results. All the returns are stationary at the level.

To check the conditional volatility, ARCH LM test is applied to detect ARCH effect. It is necessary for return's series to have ARCH effect, so that GARCH $(1,1)$ is applied. The study collected data of 41 shares two years pre and post data of Single stock futures firms from July 1, 2001 until December 30, 2010. Out of 41 shares, 27 shares exhibited ARCH effect but three companies were excluded for analysis because of violations of GARCH assumptions. A final sample of 24 shares is included for analysis.

Table 1.2. Stationary of returns

\begin{tabular}{|c|c|c|c|c|c|c|}
\hline & $\begin{array}{c}\text { Full } \\
\text { period }\end{array}$ & & PRE & & POST & \\
\hline & $\begin{array}{c}\mathrm{t}- \\
\text { Statistic } \\
-\end{array}$ & Prob.* & $\begin{array}{c}\mathrm{t}- \\
\text { Statistic } \\
-\end{array}$ & Prob.* & $\begin{array}{c}\mathrm{t}- \\
\text { Statistic } \\
-\end{array}$ & Prob.* \\
\hline ENGRO & $\begin{array}{c}29.4449 \\
-\end{array}$ & 0.0000 & $\begin{array}{c}20.6093 \\
-\end{array}$ & 0.0000 & $\begin{array}{c}20.9949 \\
-\end{array}$ & 0.0000 \\
\hline FABL & $\begin{array}{c}27.6713 \\
-\end{array}$ & 0.0000 & $\begin{array}{c}20.5057 \\
-\end{array}$ & 0.0000 & $\begin{array}{c}18.6759 \\
-\end{array}$ & 0.0000 \\
\hline FFBL & $\begin{array}{c}33.0237 \\
-\end{array}$ & 0.0000 & $\begin{array}{c}24.2463 \\
-\end{array}$ & 0.0000 & $\begin{array}{c}21.5013 \\
-\end{array}$ & 0.0000 \\
\hline FFC & $\begin{array}{c}33.7869 \\
-\end{array}$ & 0.0000 & $\begin{array}{c}25.3862 \\
-\end{array}$ & 0.0000 & $\begin{array}{c}21.4462 \\
-\end{array}$ & 0.0000 \\
\hline HUB & $\begin{array}{c}30.2433 \\
-\end{array}$ & 0.0000 & $\begin{array}{c}21.2833 \\
-\end{array}$ & 0.0000 & $\begin{array}{c}21.3392 \\
-\end{array}$ & 0.0000 \\
\hline KESC & $\begin{array}{c}25.0637 \\
-\end{array}$ & 0.0000 & $\begin{array}{c}17.3946 \\
-\end{array}$ & 0.0000 & $\begin{array}{c}18.3587 \\
-\end{array}$ & 0.0000 \\
\hline LUCKY & 29.1649 & 0.0000 & $\begin{array}{c}21.1245 \\
-\end{array}$ & 0.0000 & $\begin{array}{c}19.9003 \\
-\end{array}$ & 0.0000 \\
\hline MPLF & -29.709 & 0.0000 & $\begin{array}{c}21.2602 \\
-\end{array}$ & 0.0000 & $\begin{array}{c}20.7242 \\
-\end{array}$ & 0.0000 \\
\hline NML & $\begin{array}{c}-29.981 \\
-\end{array}$ & 0.0000 & $\begin{array}{c}22.0648 \\
-\end{array}$ & 0.0000 & $\begin{array}{c}19.9915 \\
-\end{array}$ & 0.0000 \\
\hline PIA & $\begin{array}{c}33.8942 \\
-\end{array}$ & 0.0000 & $\begin{array}{c}25.7774 \\
-\end{array}$ & 0.0000 & $\begin{array}{c}23.2023 \\
-\end{array}$ & 0.0000 \\
\hline PIOC & 26.6361 & 0.0000 & 19.2042 & 0.0000 & 18.5536 & 0.0000 \\
\hline
\end{tabular}




\begin{tabular}{|c|c|c|c|c|c|c|}
\hline \multicolumn{6}{|c|}{ Business Review - Volume 8 Number 1} & January \\
\hline & & & - & & & \\
\hline PSO & $\begin{array}{c}-31.438 \\
-\end{array}$ & 0.0000 & $\begin{array}{c}21.7735 \\
-\end{array}$ & 0.0000 & 22.6163 & 0.0000 \\
\hline PTCL & $\begin{array}{c}32.0945 \\
-\end{array}$ & 0.0000 & $\begin{array}{c}23.7087 \\
-\end{array}$ & 0.0000 & $\begin{array}{c}-21.765 \\
-\end{array}$ & 0.0000 \\
\hline SNGP & 31.9307 & 0.0000 & $\begin{array}{c}22.0872 \\
-\end{array}$ & 0.0000 & $\begin{array}{c}23.2462 \\
-\end{array}$ & 0.0000 \\
\hline SSGP & $\begin{array}{c}-26.737 \\
-\end{array}$ & 0.0000 & $\begin{array}{c}18.8382 \\
-\end{array}$ & 0.0000 & $\begin{array}{c}18.9401 \\
-\end{array}$ & 0.0000 \\
\hline TELE & $\begin{array}{c}28.2739 \\
-\end{array}$ & 0.0000 & $\begin{array}{c}20.6682 \\
-\end{array}$ & 0.0000 & $\begin{array}{c}19.4902 \\
-\end{array}$ & 0.0000 \\
\hline $\mathrm{ABL}$ & $\begin{array}{c}26.8719 \\
-\end{array}$ & 0.0000 & $\begin{array}{c}18.0994 \\
-\end{array}$ & 0.0000 & $\begin{array}{c}20.2883 \\
-\end{array}$ & 0.0000 \\
\hline NETSOL & $\begin{array}{c}25.5238 \\
-\end{array}$ & 0.0000 & $\begin{array}{c}18.6514 \\
-\end{array}$ & 0.0000 & $\begin{array}{c}17.5892 \\
-\end{array}$ & 0.0000 \\
\hline FCCL & $\begin{array}{c}25.0909 \\
-\end{array}$ & 0.0000 & $\begin{array}{c}20.1877 \\
-\end{array}$ & 0.0000 & $\begin{array}{c}18.7955 \\
-\end{array}$ & 0.0000 \\
\hline CSAP & $\begin{array}{c}25.9801 \\
-\end{array}$ & 0.0000 & $\begin{array}{c}20.1524 \\
-\end{array}$ & 0.0000 & $\begin{array}{c}17.1362 \\
-\end{array}$ & 0.0000 \\
\hline ATRL & $\begin{array}{c}23.5107 \\
-\end{array}$ & 0.0000 & $\begin{array}{c}18.7351 \\
-\end{array}$ & 0.0000 & $\begin{array}{c}15.2765 \\
-\end{array}$ & 0.0000 \\
\hline PRL & $\begin{array}{c}23.4802 \\
-\end{array}$ & 0.0000 & $\begin{array}{c}17.4566 \\
-\end{array}$ & 0.0000 & $\begin{array}{c}15.8312 \\
-\end{array}$ & 0.0000 \\
\hline PICT & $\begin{array}{c}26.8719 \\
-\end{array}$ & 0.0000 & $\begin{array}{c}18.0994 \\
-\end{array}$ & 0.0000 & $\begin{array}{c}20.2883 \\
-\end{array}$ & 0.0000 \\
\hline WTL & 32.3585 & 0.0000 & 22.1253 & 0.0000 & 23.0351 & 0.0000 \\
\hline
\end{tabular}

Table 1.3. Pre diagnostic ARCH LM test

\begin{tabular}{cccc}
\hline S.no & Name & F-statistic & Prob \\
\hline 1 & ENGRO & 28.76 & 0.00 \\
2 & FABL & 4.11 & 0.04 \\
3 & FFBL & 14.12 & 0.00 \\
4 & FFC & 145.90 & 0.00 \\
5 & HUB & 88.88 & 0.00 \\
6 & KESC & 100.90 & 0.00 \\
7 & LUCKY & 35.06 & 0.00 \\
8 & MPLF & 27.01 & 0.00 \\
9 & NML & 40.61 & 0.00 \\
10 & PIA & 25.43 & 0.00 \\
11 & PIOC & 9.74 & 0.00 \\
\hline
\end{tabular}




\begin{tabular}{cccc}
\hline Business Review - Volume 8 Number 1 & & January - \\
\hline & & & \\
\hline 12 & PSO & 17.90 & 0.00 \\
13 & PTCL & 27.24 & 0.00 \\
14 & SNGP & 4.24 & 0.04 \\
15 & SSGP & 91.37 & 0.00 \\
16 & TELE & 3.33 & 0.07 \\
17 & ABL & 5.31 & 0.02 \\
18 & NETSOL & 7.17 & 0.01 \\
19 & FCCL & 122.85 & 0.00 \\
20 & CSAP & 6.20 & 0.01 \\
21 & ATRL & 150.87 & 0.00 \\
22 & PRL & 66.36 & 0.00 \\
23 & PICT & 20.25 & 0.00 \\
24 & WTL & 174.51 & 0.00 \\
\hline
\end{tabular}

Table 1.4. F-test for difference in variances

\begin{tabular}{ccccc}
\hline \multicolumn{5}{c}{ Change in standard deviation } \\
\hline Name & Pre-SSF & Post-SSF & Change & P-value \\
ENGRO & 0.00090 & 0.00059 & -0.00031 & 0.0000 \\
FABL & 0.00076 & 0.00085 & 0.00009 & 0.1035 \\
FFBL & 0.00176 & 0.00065 & -0.00111 & 0.0000 \\
FFC & 0.00078 & 0.00043 & -0.00035 & 0.0000 \\
HUB & 0.00091 & 0.00074 & -0.00017 & 0.0108 \\
KESC & 0.00116 & 0.00087 & -0.00030 & 0.0005 \\
LUCKY & 0.00082 & 0.00074 & -0.00008 & 0.1333 \\
MPLF & 0.00104 & 0.00076 & -0.00028 & 0.0003 \\
NML & 0.00144 & 0.00111 & -0.00033 & 0.0021 \\
PIA & 0.00093 & 0.00184 & 0.00090 & 0.0000 \\
PIOC & 0.00107 & 0.00086 & -0.00021 & 0.0083 \\
PSO & 0.00074 & 0.00072 & -0.00003 & 0.3437 \\
PTCL & 0.00052 & 0.00059 & 0.00007 & 0.0853 \\
\hline
\end{tabular}




\begin{tabular}{ccccc}
\hline Business Review - Volume 8 Number 1 & & January - June 2 \\
\hline & & & \\
\hline SNGP & 0.00123 & 0.00089 & -0.00034 & 0.0002 \\
SSGP & 0.00066 & 0.00066 & 0.00001 & 0.4610 \\
TELE & 0.00091 & 0.00129 & 0.00038 & 0.0001 \\
ABL & 0.00094 & 0.00073 & -0.00021 & 0.0026 \\
NETSOL & 0.00096 & 0.00120 & 0.00024 & 0.0059 \\
FCCL & 0.00068 & 0.00170 & 0.00102 & 0.0000 \\
CSAP & 0.00082 & 0.00120 & 0.00039 & 0.0000 \\
ATRL & 0.00093 & 0.00142 & 0.00048 & 0.0000 \\
PRL & 0.00072 & 0.00080 & 0.00007 & 0.1394 \\
PICT & 0.00094 & 0.00073 & -0.00021 & 0.0026 \\
WTL & 0.00077 & 0.00288 & 0.00211 & 0.0000
\end{tabular}

Decrease in S.D

13
Increase in S.D.

11

\begin{tabular}{cccc}
$\mathbf{s}$ & $\mathbf{n s}$ & $\mathbf{s}$ & $\mathbf{n s}$ \\
11 & 2 & 8 & 3 \\
\hline
\end{tabular}

${ }^{*} s=$ significant, $\mathrm{ns}=$ not significant

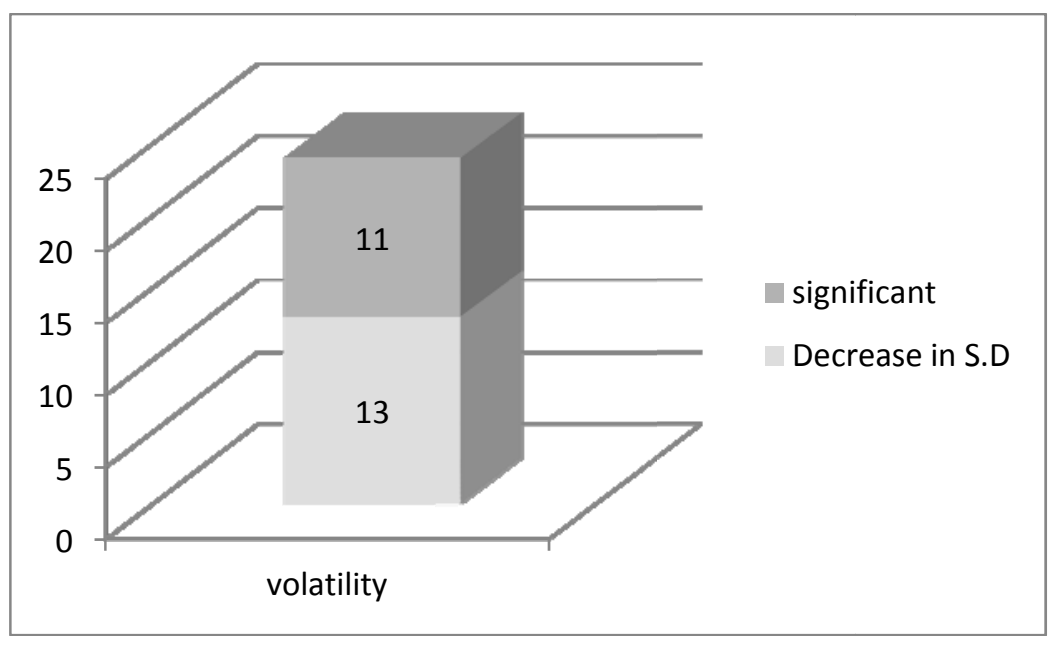




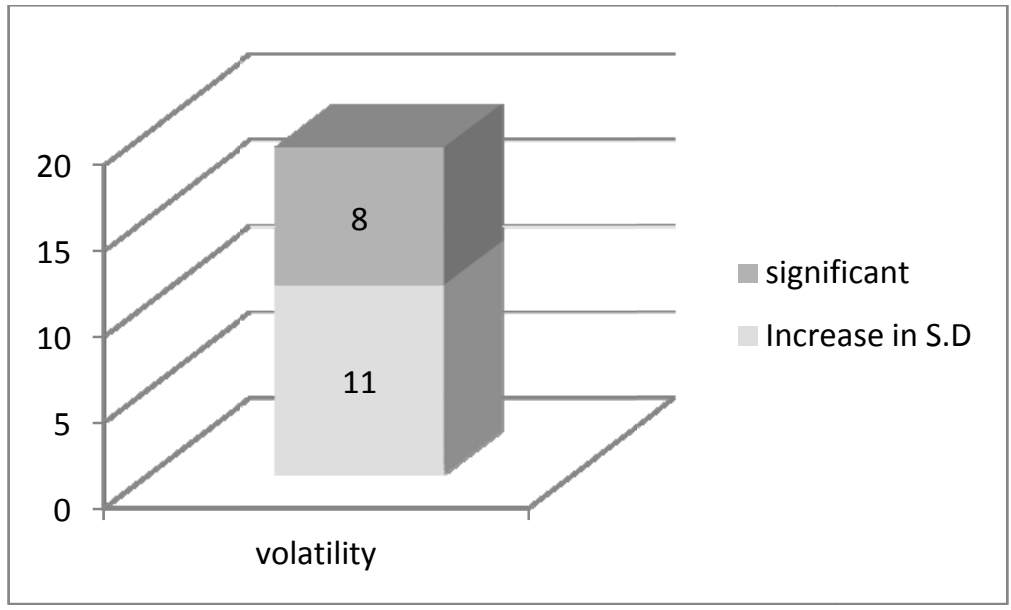

F-test analysis

As the results show more decrease in volatility after single stock futures trading, this is in conformance with stabilizing effect of futures trading.

Table 1.5. Individual company's response to stock futures trading

\begin{tabular}{ccc}
\hline & ARCH-GARCH effects & \multicolumn{1}{c}{ Companies } \\
\hline- & Decrease in ARCH & ENGRO,FFC,SNGP,CSAP,FCCL,NETSOL,ABL. \\
+ & Increase in GARCH & \\
+ & Increase in AR root & \\
& Interpretation & Slower incorporation of news \\
& & Large impact of old news on volatility \\
& & Long period of volatility \\
& & FABL,HUB,LUCKY,MPLF,PIOC,PSO,PTCL,TELE \\
+ & Increase in ARCH & \\
- & Decrease in GARCH & \\
& Decrease in AR root & \\
& Interpretation & Faster incorporation of news \\
\hline
\end{tabular}


Small impact of old news on volatility

Short period of volatility

- $\quad$ Decrease in ARCH

$+\quad$ Increase in GARCH

- $\quad$ Decrease in AR root Interpretation

$+\quad$ Increase in ARCH NML

- $\quad$ Decrease in GARCH

$+\quad$ Increase in AR root Interpretation

$+\quad$ Increase in $\mathrm{ARCH}$

$+\quad$ Increase in GARCH

$+\quad$ Increase in AR root Interpretation
FFBL,KESC,SSGP.

Slower incorporation of news

Large impact of old news on volatility

Short period of volatility

Faster incorporation of news

Small impact of old news on volatility

Long period of volatility

PIA,WTL,PICT,PRL,ATRL.

Faster incorporation of news

Large impact of old news on volatility

Long period of volatility

Above table shows the individual company response towards futures trading. These responses are categorized in five different patterns and their interpretation. 
Table 1.6. Summary of GARCH(1,1) analysis

\begin{tabular}{|c|c|c|c|c|c|c|c|c|}
\hline No. & SSF & DF & ARCH & \multicolumn{2}{|c|}{ GARCH } & AR root & & \\
\hline 1 & ENGRO & - & - & \multicolumn{2}{|l|}{+} & + & & \\
\hline 2 & FABL & - & + & \multicolumn{2}{|l|}{-} & - & & \\
\hline 3 & FFBL & - & - & \multicolumn{2}{|l|}{+} & - & & \\
\hline 4 & $\mathrm{FFC}$ & - & - & \multicolumn{2}{|l|}{+} & + & & \\
\hline 5 & HUB & - & + & \multicolumn{2}{|l|}{-} & - & & \\
\hline 6 & KESC & - & - & \multicolumn{2}{|l|}{+} & - & & \\
\hline 7 & LUCKY & - & + & \multicolumn{2}{|l|}{-} & - & & \\
\hline 8 & MPLF & - & + & \multicolumn{2}{|l|}{-} & - & & \\
\hline 9 & NML & - & + & \multicolumn{2}{|l|}{-} & + & & \\
\hline 10 & PIA & + & + & \multicolumn{2}{|l|}{+} & + & & \\
\hline 11 & PIOC & - & + & \multicolumn{2}{|l|}{-} & - & & \\
\hline 12 & PSO & + & + & \multicolumn{2}{|l|}{-} & - & & \\
\hline 13 & PTCL & + & + & \multicolumn{2}{|l|}{-} & - & & \\
\hline 14 & SNGP & - & - & \multicolumn{2}{|l|}{+} & + & & \\
\hline 15 & SSGP & - & - & \multicolumn{2}{|l|}{+} & - & & \\
\hline 16 & TELE & + & + & \multicolumn{2}{|l|}{-} & - & & \\
\hline 17 & WTL & + & + & \multicolumn{2}{|l|}{+} & + & & \\
\hline 18 & PICT & - & + & \multicolumn{2}{|l|}{+} & + & & \\
\hline 19 & PRL & - & + & \multicolumn{2}{|l|}{+} & + & & \\
\hline 20 & ATRL & - & + & \multicolumn{2}{|l|}{+} & + & & \\
\hline 21 & CSAP & + & - & \multicolumn{2}{|l|}{+} & + & & \\
\hline 22 & FCCL & + & - & \multicolumn{2}{|l|}{+} & + & & \\
\hline 23 & NETSOL & + & - & \multicolumn{2}{|l|}{+} & + & & \\
\hline 24 & $\mathrm{ABL}$ & - & - & \multicolumn{2}{|l|}{+} & + & & \\
\hline \multicolumn{2}{|c|}{ Spot volatility } & \multicolumn{2}{|c|}{ Dissemination rate } & \multicolumn{3}{|c|}{ Long-term impact } & $\begin{array}{r}\text { Persist } \\
\text { sho } \\
\end{array}$ & $\begin{array}{l}\text { nce of } \\
\text { ks }\end{array}$ \\
\hline Decrease & Increase & Decrease & Increase & Decrease & Inc & & Decrease & Increase \\
\hline 16 & 8 & 10 & 14 & 9 & & 5 & 11 & 13 \\
\hline ns & ns & ns & ns & ns & $\mathrm{s}$ & ns & & \\
\hline 13 & 3 & 1 & 14 & 1 & 13 & 2 & & \\
\hline
\end{tabular}


https://ir.iba.edu.pk/businessreview/vol8/iss1/8

DOI: https://doi.org/10.54784/1990-6587.1219

Business Review - Volume 8 Number 1

January - June 2013

$*_{\mathrm{s}}=$ significant, $\mathrm{ns}=$ not significant
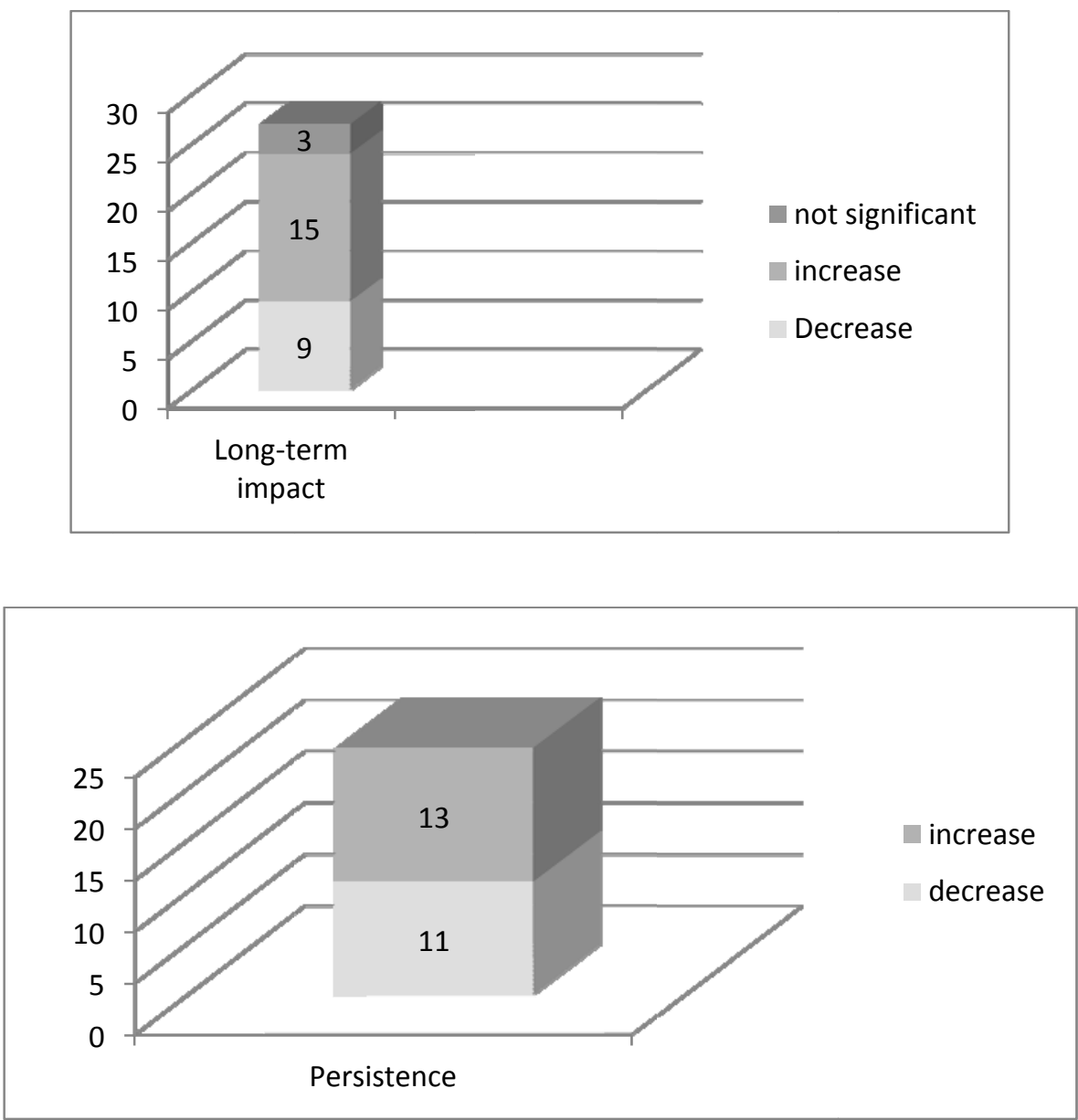


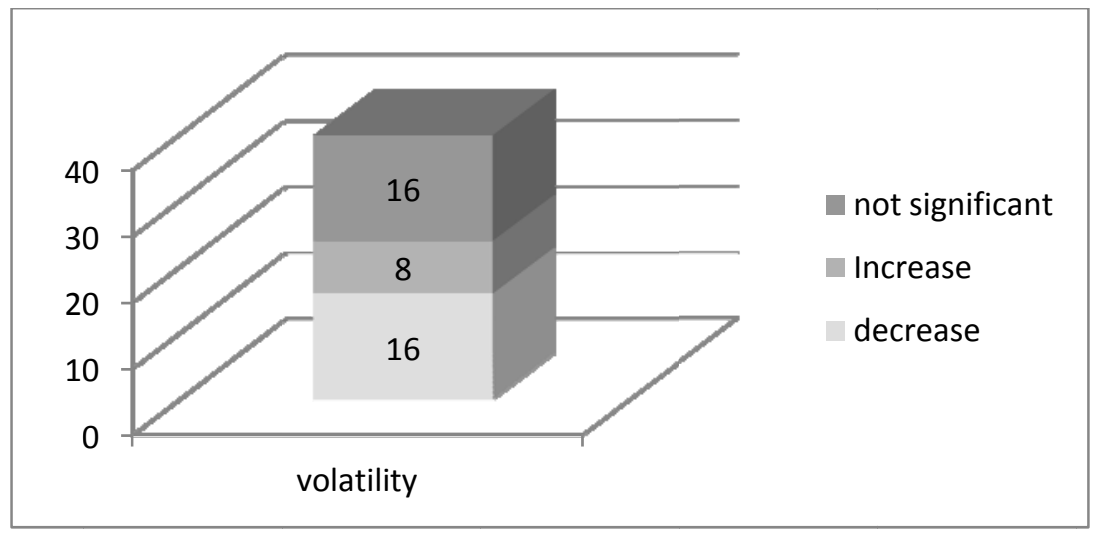

\section{GARCH (1,1) analysis}

A statistically significant decrease was experienced by the majority of companies with only five shares showed a statistically significant increase in volatility. Fourteen shares showed a significant increase in the rate of news incorporation as compared to nine shares showing significant decrease in dissemination rate. Similarly, there was a significant increase in long-term impact of thirteen shares with eight showing decrease in old news impact. Increase in news incorporation in prices and long-term impact of old news lead to increase in persistence of shock effect in thirteen shares. ARCH LM test is applied again to check remaining ARCH effect. In all the shares, there was no ARCH effect left over.

Table 1.7. Post diagnostic ARCH LM test

\begin{tabular}{lrrrrrr}
\hline & \multicolumn{1}{l}{ FULL } & \multicolumn{2}{l}{ PRE } & \multicolumn{2}{l}{ POST } \\
\hline Name & \multicolumn{1}{l}{ F-statistic } & Prob.* $^{*}$ & F-statistic & Prob.* $^{*}$ & F-statistic & Prob.* $^{*}$ \\
ENGRO & 0.28363 & 0.5945 & 0.101817 & 0.7498 & 0.270438 & 0.6033 \\
FABL & $8.12 E-05$ & 0.9928 & 0.056489 & 0.8122 & 0.270438 & 0.6033 \\
FFBL & 0.500265 & 0.4795 & 0.714687 & 0.3983 & 0.043029 & 0.8358 \\
FFC & 0.011526 & 0.9145 & 0.002426 & 0.9607 & 0.145052 & 0.7035 \\
HUB & 0.092346 & 0.7613 & 0.110351 & 0.7399 & 0.132487 & 0.716 \\
KESC & 0.297581 & 0.5855 & 0.387924 & 0.5337 & 0.005348 & 0.9417 \\
LUCKY & 0.018597 & 0.8916 & 0.12658 & 0.7222 & 0.069259 & 0.7925 \\
MPLF & 0.038806 & 0.8439 & 0.006397 & 0.9363 & 0.059263 & 0.8078 \\
NML & 2.27312 & 0.132 & 1.121221 & 0.2902 & 1.030216 & 0.3106 \\
PIA & 0.825346 & 0.3638 & 0.377225 & 0.5394 & 0.365154 & 0.5459 \\
PIOC & 0.020692 & 0.8856 & 0.011685 & 0.914 & 0.16592 & 0.6839 \\
\hline
\end{tabular}




\begin{tabular}{lrrrrrr}
\hline \multicolumn{3}{c}{ Business Review - Volume 8 Number 1 } & \multicolumn{3}{c}{ January - June 2013 } \\
\hline & & & & & & \\
\hline PSO & 0.009179 & 0.9237 & 0.068158 & 0.7941 & 0.460655 & 0.4976 \\
PTCL & 0.001008 & 0.9747 & 0.001533 & 0.9688 & 0.002449 & 0.9605 \\
SNGP & 0.60092 & 0.4384 & 0.720607 & 0.3964 & 0.012194 & 0.9121 \\
SSGP & 0.054115 & 0.8161 & 0.073785 & 0.786 & 0.029758 & 0.8631 \\
TELE & 0.112181 & 0.7377 & $1.17 \mathrm{E}-05$ & 0.9973 & 0.051665 & 0.8203 \\
WTL & 0.862318 & 0.3533 & 0.116504 & 0.733 & 0.742151 & 0.3894 \\
PICT & 0.521795 & 0.4702 & 0.498874 & 0.4803 & 0.00585 & 0.9391 \\
PRL & 0.006386 & 0.9363 & 0.047317 & 0.8279 & 1.114346 & 0.2917 \\
ATRL & 0.000899 & 0.9761 & 0.088883 & 0.7657 & 0.000747 & 0.9782 \\
CSAP & 0.05644 & 0.8123 & 0.292578 & 0.5888 & 0.025685 & 0.8727 \\
FCCL & 2.606255 & 0.1068 & 0.140523 & 0.7079 & 10.10767 & 0.1600 \\
NETSOL & 0.008391 & 0.927 & 0.076264 & 0.7825 & 0.005595 & 0.9404 \\
ABL & 1.904208 & 0.1679 & 0.128298 & 0.7204 & 1.465631 & 0.2266 \\
\hline
\end{tabular}

\section{Discussion}

This study applied traditional measures of volatility (F-test) as well as econometric techniques (GARCH modeling). Both analyses showed that in the majority of cases, there were mixed effect on volatility after futures trading. It is reasonable to conclude that SSF's trading lead to lower spot market volatility. The results are against complete market's theory, diminishing short sale restriction theory and improved information environment hypothesis, which states that decrease in volatility after derivative trading. This study is aligned with Chau et al.(2005) and Hung et al. (2003). With respect to changes in structure of volatility, the increased rate of news into share prices has been followed by long periods of excessive price movements, which lead to the extended period of volatility. It is therefore concluded that futures trading has attracted both informed as well as uninformed traders. Faster incorporation of news in share price attracted informed traders. Larger contribution of old news to volatility show that uninformed traders are attracted towards futures markets. The increase in ARCH and GARCH term resulted in the extended period of volatility (persistence of shocks effect).

\section{Conclusion}

Single stock futures lead mixed effect with respect to level of volatility. SSF's contracts altered the structure of volatility with an increase in ARCH term, GARCH term and also Autoregressive term. Increase in ARCH and GARCH term suggests that SSFs has attracted both informed as well uniformed investors who have led to increase persistence of shock's effect. Consequently, this study is aligned with majority of past studies which showed no effect. As this study shows persistency of shocks effect, so strict regulations should be uphold with respect to futures trading. 


\section{Recommendations}

This study can be extended by analyzing good news and bad news impact on volatility after stock futures trading. Asymmetric models like T-GARCH and E-GARCH can be applied. Sector wise analysis can be conducted to analyze the effect of stock futures on underlying spot prices of the specific sector.

\section{References}

Ahmad, H., Shah, A, Z., and Shah, I. (2010). "Impact of Futures Trading on Spot Price Volatility: Evidence from Pakistan', International Research Journal of Finance and Economics. Issue 59.

Aitken, M. \& Segara, R. 2005. Impact of warrant introduction on the behavior of underlying stocks: Australian evidence. Accounting and Finance, 45(1).

Ang,J., and Cheng,Y(2005).Financial innovations and market efficiency: the case of single stock futures. Journal of Applied Finance. EBSCO host Business source complete.

Arditti, F. \& John, K. (1980), “Spanning the State Space with Options,” Journal of Financial and Quantitative Analysis, Vol. 15.

Bae, S.C., Kwon, T.H. \& Park, J.W. 2004. Futures trading, spot market volatility, and market efficiency: the case of the Korean index futures markets. The Journal of Futures Markets, 24(12).

Bologna, P. \& Cavallo, L. 2002. Does the introduction of stock index futures effectively reduce stock market volatility? Is the futures effect immediate? Evidence from the Italian stock exchange using GARCH. Applied Financial Economics.

Butterworth, D. 2000. The impact of futures trading on underlying stock index volatility: the case of the FTSE Mid 250 contract. Applied Economics Letters.

Chatrath, A., Ramchander, S. \& Song, F. 1995. Does options trading lead to greater cash market volatility? The Journal of Futures Markets.

Chau, F., Holmes, P. \& Paudyal, K. 2005. The impact of single stock futures on feedback trading and the market dynamics of the cash market. Working Paper Series No. 05/12. University of Durham.

Clarke, M., Gannon, G. \& Vinning, R. 2007. The impact of warrant introduction: Australian experience. School Working Paper Series No. 2007/11.

Darrat, A.F. \& Rahman, S. 1995. Has futures trading activity caused stock price volatility? The Journal of Futures Markets, 15(5).

De Beer,J. (2008). "The impact of single stock futures on South African equity market'.M.Com Thesis. University of South Africa. 
Dennis, S.A. \& Sim, A.B. 1999. Share price volatility with the introduction of single share futures on the Sydney Futures Exchange. International Review of Financial Analysis, 8(2).

Detemple, J. \& Selden, L. (1991), “A General Equilibrium Analysis of Option and Stock Market Interactions," International Economic Review, Vol. 32.

Drimbetas, E., Sariannidis, N. \& Porfiris, N. 2007. The effect of derivatives trading on volatility of the underlying asset: evidence from the Greek stock market. Applied Financial Economics, 17(2).

Elfakhani, S. \& Chaudhury, M. 1995. The volatility effect of option listing: some Canadian evidence. The Quarterly Review of Economics and Finance.

Faff, R. \& Hillier, D. 2005. Complete markets, informed trading and equity option introductions. Journal of Banking and Finance.

Figlewski, S. \& Webb, G. P. (1993), “Options, Short Sales, and Market Completeness,” Journal of Finance, Vol. 48.

Hung, M.W., Lee, C.F. \& So, L.C. 2003. Impact of foreign-listed single stock futures on the domestic underlying stock markets. Applied Economics Letters.

Jones,T. and Brooks,R. (2005).An analysis of single stock futures trading in U.S. Financial services review. EBSCO host Business source complete.

Khan, S. 2006. "Role of futures market on volatility and price discovery of the spot market: Evidence from the Pakistan's stock market", The Lahore Journal of Economics, vol 11, No.2.

Khan, S., Shah, A. and Abbas, Z. (2011) “'Impact of Single Stock Futures Trading on Stock Price Volatility of Underlying Stocks: Empirical Evidence from Pakistan's Stock Market', Journal of Basic and Applied Scientific Research, 1(11).

Khan,S. and Hijazi,T.S. (2009).Single Stock Futures Trading and Stock Price Volatility: Empirical Analysis. The Pakistan Development Review.

Kruger, WdK. 2000. Equity index futures contracts and share price volatility: a South African perspective. Potchefstroom University for Christian Higher Education.

Kumar, K.K. \& Mukhopadhyay, C. 2004. Impact of futures introduction on underlying NSE Nifty volatility, in Proceedings of the International Conference 2003 on Business and Finance Volume III. Editors N. Swain, D.K. Malhotra, B. Roy. India: ICFAI University Press:326-341.

Mazouz, K. \& Bowe, M. 2006. The volatility effect of futures trading: evidence from LSE traded stocks listed as individual equity futures contracts on LIFFE. International Review of Financial Analysis, 15(1). 
Mazouz, K. 2004. The effect of CBOE option listing on the volatility of NYSE traded stocks: a time-varying variance approach. Journal of Empirical Finance, 11(5).

McKenzie, M.D., Brailsford, T.J. \& Faff, R.W. 2001. New insights into the impact of the introduction of futures trading on stock price volatility. The Journal of Futures Markets, 21(3).

Miller, E.M. (1977), "Risk, Uncertainty, and Divergence of Opinion," Journal of Finance, Vol. 32 .

Mukherjee,A.(2006). Why India is crazy about single stock futures. Bloomberg.

Oehley, D.J. 1995. The effect of the introduction of index future trading on underlying index volatility. University of the Witwatersrand.

Parsons, J. 1998. Futures trading and cash market volatility. University of Stellenbosch.

Paulden,P(2005).Future shock. Institutional investor. EBSCO host Business source complete.

Peat, M. \& McCorry, M. 1997. Individual share futures contracts: the economic impact of their introduction on the underlying equity market. Working Paper Series No.74. University of Technology, Sydney.

Raul,R.K. (2004). Stock futures in derivative family. The institute of costs and works accountants of India.

Robbani,M.G. and Bhuyan,R.(2005). Futures trading activity and stock price volatility. Derivative, Use, Trading and regulation. EBSCO host Business source complete.

Ross, S. (1977), “Options and Efficiency,” Quarterly Journal of Economics, Vol. 90.

Smit, E.vdM. \& Nienaber, H. 1997. Futures-trading activity and share price volatility in South Africa. The Investment Analysts Journal.

Swart, A. 1998. The impact of share index futures trading on the volatility and liquidity of the underlying assets on the Johannesburg Stock Exchange. University of Cape Town.

Vanden Baviere, L. \& De Villiers, J.U. 1997. Share volatility after the introduction of index futures. The Investment Analysts Journal. 
ANNEXURE

Sample companies included for analysis

\begin{tabular}{|c|c|c|c|}
\hline S.No & Code & Company Name & Listing date \\
\hline 1 & DSFL & Dewan Salman Fibers Ltd. & 1-Jul-01 \\
\hline 2 & ENGRO & Engro Chemicals Ltd. & 1-Jul-01 \\
\hline 3 & FFC & Fauji Fertilizer Co. Ltd. & 1-Jul-01 \\
\hline 4 & HUBC & Hub Power Co Ltd. & 1-Jul-01 \\
\hline 5 & MCB & MCB Bank Limited. & 1-Jul-01 \\
\hline 6 & NML & Nishat Mills Ltd. & 1-Jul-01 \\
\hline 7 & PIAA & Pakistan International Airline (A) & 1-Jul-01 \\
\hline 8 & PSO & Pakistan State Oil Co Ltd. & 1-Jul-01 \\
\hline 9 & PTCL & Pakistan Telecommunication Ltd. & 1-Jul-01 \\
\hline 10 & SNGP & Sui Northern Gas Pipe Line Ltd. & 1-Jul-01 \\
\hline 11 & IBFL & Ibrahim Fibers Ltd & 1-Jan-02 \\
\hline 12 & FFBL & Fauji Fertilizer Bin Qasim Ltd. & 25-Nov-03 \\
\hline 13 & DGKC & D. G. Khan Cement Co. Ltd. & 21-Jun-04 \\
\hline 14 & SSGC & Sui Southern Gas Co Ltd. & 21-Jun-04 \\
\hline 15 & LUCK & Lucky Cement Limited. & 21-Jun-04 \\
\hline 16 & MLCF & Maple Leaf Cement Factory Ltd. & 21-Jun-04 \\
\hline 17 & NBP & National Bank Of Pakistan & 21-Jun-04 \\
\hline 18 & POL & Pakistan Oilfields Limited. & 21-Jun-04 \\
\hline 19 & AKBL & Askari Commercial Bank Limited. & 20-Sep-2004 \\
\hline 20 & BOP & Bank Of Punjab & 20-Sep-2004 \\
\hline 21 & FABL & Faysal Bank Limited. & 20-Sep-2004 \\
\hline 22 & TELE & Telecard Ltd. & 20-Sep-2004 \\
\hline 23 & KESC & Karachi Electric Supply Corporation & 20-Feb-06 \\
\hline 24 & PIOC & Pioneer Cement Ltd. & $20-F e b-06$ \\
\hline 25 & WTL & World call telecom & 24-Mar-08 \\
\hline 26 & AICL & Adamjee Insurance & 24-Mar-08 \\
\hline 27 & ABL & Allied Bank Limited & 24-Mar-08 \\
\hline 28 & AHSL & Arif Habib Sec. & 24-Mar-08 \\
\hline 29 & PKGS & Packages Ltd. & 24-Mar-08 \\
\hline 30 & NRL & National Refinery & 24-Mar-08 \\
\hline 31 & NIB & NIB Bank Limited & 24-Mar-08 \\
\hline 32 & NETSOL & Netsol Technologies & 24-Mar-08 \\
\hline 33 & JSCL & Jah.Siddiq.Co. & 24-Mar-08 \\
\hline 34 & FCCL & Fauji Cement & 24-Mar-08 \\
\hline 35 & CSAP & Crescent Steel SPOT & 24-Mar-08 \\
\hline 36 & ANL & Azgard Nine & 24-Mar-08 \\
\hline 37 & ATRL & Attock Refinery Limited & 24-Mar-08 \\
\hline 38 & SNBL & Soneri Bank & 24-Mar-08 \\
\hline 39 & PRL & Pak Refinery & 24-Mar-08 \\
\hline 40 & PICT & Pak.Int.Con.Ter. & 24-Mar-08 \\
\hline 41 & BAHL & Bank Al-Habib Ltd & 24-Mar-08 \\
\hline
\end{tabular}

